\title{
What unites Europe and what divides it? Solidarity and the European heritage reconsidered
}

\author{
Gerard Delanty
}

\author{
Correspondence: \\ g.delanty@sussex.ac.uk \\ Department of Sociology, University \\ of Sussex, Brighton BN19QE, UK
}

\begin{abstract}
Despite the on-set on new divisions, there is a strong case to be made for the view that ultimately Europe is more united than divided. There is still significant continuity with the post-war project of reconstruction and peace and that this common ground that constitutes the European heritage needs to be given greater recognition. One of the defining features of European self-understanding is opposition to war.
\end{abstract}

Keywords: European heritage, Solidarity, Democracy, Cosmopolitanism, Brexit, EU, European integration

Is Europe more united today than divided? This, in the most general terms, is the question I pose and seek to answer. ${ }^{1}$ I shall state my argument before I look, in the second part of my essay, at the nature of divisions: despite the on-set on new divisions, there is a strong case to be made for the view that ultimately Europe is more united than divided. The term united can of course mean different things. It does not mean, and I certainly do not intend it to mean, politically united in the sense, for example, that in 1990 Germany became united. To a degree, the post-second world war project of European integration has brought about the integration of economic and other steering mechanisms. The single currency is one such example, even if it also has engendered new divisions.

Europe is united in a different and more philosophical sense and for which a longer historical perspective is needed. Since the end of the first world war European intellectuals became increasingly aware of both common bonds that united the war torn European countries and the need to build upon their shared heritage Harrington (2016), Rosenboim (2017). That commitment did not stop the descent into the worst war in the history of human societies, but offered a legacy on which Europe could rebuild itself after 1945. This heritage is still with us and has grown to encompass wide social strata. Until recently, the idea of Europe was the aspiration of elites, political and intellectual elites of both the right and the left. Initially it was more attractive to the right, but came to be accepted by the left.

Today the idea of Europe is part of the self-understanding of very large segments of the population, in particular of young people, who have been born as European citizens. Letting aside, for now, the extent of the Europeanisation of identities, the

(c) The Author(s). 2018 Open Access This article is distributed under the terms of the Creative Commons Attribution 4.0 International License (http://creativecommons.org/licenses/by/4.0/), which permits unrestricted use, distribution, and reproduction in any medium, provided you give appropriate credit to the original author(s) and the source, provide a link to the Creative Commons license, and indicate if changes were made. 
important point is that since 1945, but going back the interwar-period, a cognitive shift occurred that had far-reaching political and cultural significance. After 1945 the idea of Europe came to signify a profound opposition to war, as in the phrase Nie Wieder, 'never again war'. The generation who forged the project of European integration that culminated in the Treaty of Rome was animated by the belief in the need to create a lasting peace in a continent that had within, living memory, witnessed three wars. That sense of what Strath (2016) has called a 'utopia of peace' has lost its force today, now that the goal has been achieved and the memory of the war no longer is a living or collective memory. However, I argue that the essential utopia of peace has survived and has entered the historical memory of Europeans in ways that are not always evident but exert a strong influence.

In my book The European Heritage, I argued that one of the defining features of European self-understanding since 1945 is opposition to war. War within Europe has become a thing of the past (Delanty 2018). Significant progress has been made in resolving the last vestige of military conflict within the European area over Turkish occupation of Cyprus. Despite the danger posed by Brexit, civil war in Northern Ireland is not likely to reoccur. External war is not to be discounted, as in the case of Iraq war in 2003, but here too there is little appetite for armed conflict. The world-wide tendency is towards an increase in civil strife within nations rather than between them. This is vividly reflected in the resurgence of the question of Catalan independence, but in this case, as the example of Corsican nationalism also attests, there is little appetite for violence.

This is all in stark contrast to the turbulent and often violent history of Europe. The past seventy years has been remarkably peaceful and which can be seen as a part of a world-wide trend towards the relative decrease in violence. The exception is the war that followed the break-up of the former Yugoslavia in the early 1990s. It is of course the case that for several decades this peace existed within the context of a political order of dictatorships. Yet, with the exception of war in the former Yugoslavia, the transition has been remarkably peaceful. The spread of democracy - since 1980 in the Iberian Peninsula and after 1990 in central and eastern Europe - has made it possible for Europe to re-appraise its history and forge a new self-understanding. This cannot be from the position of having reached the 'end of history' since this period has been marked by events that while largely peaceful have been nonetheless tumultuous. There may no longer be a major clash of political ideologies, but there is a cultural clash of identities and of socio-cultural milieus, as is evident from Brexit Britain today and the disturbing trend towards authoritarian democracy in Poland and Hungary. While a newly found unity has been attained in peace, new divisions have resulted from the very means that made this peace possible. Democracy does not overcome differences. It makes possible pluralisation and rights based claims. It also makes possible the reinterpretation of the past as the received accounts are discredited or contested. It has created the conditions in which the legacy of history can be examined from positions that previously were silenced. This situation when combined with the wider transformation of culture has opened up political community to new challenges.

It is thus my contention that since 1945 opposition to war has been a growing principle that has united Europeans and could be said to be the defining element in contemporary European self-understanding. It is a significant basis of European solidarity 
and can also be seen, following Walter Benjamin, as an expression of anamnestic solidarity with the victims of history. Anti-war solidarity made possible the largest protests in European history in 2003 when millions of people took to the streets on 15 and 16 February to protest against the Anglo-American led war in Iraq. The largest protests were in Rome with some three million people, 1.5 million in Madrid and one million sized protests in other cities, such as London and Barcelona. These protests, which were part of a global anti-war movement, reveal the shaping of a cosmopolitan ethic of solidarity and the centrality of the idea of human dignity and anti-war. The aversion to war in Europe since 1945 has been a strong force in shaping European consciousness and, with the dark legacy of the Holocaust, it has made possible a Europeanisation of memory in which older memories provide a pattern for new memories. It is in this sense, then, possible to say that there is something binding Europe together.

Discussion of the current situation of Europe in the press and public sphere naturally focusses on the present. A sociological and historical perspective offers a deeper view of the current situation that sees in the crises of the moment both continuity and rupture. Making sense of current times should not lose sight of the continuities of the past.

This all raises the question what is the present time. Here I think some periodisation is useful, since the present needs to be defined in relation to temporal horizons. As I see it, there have been four points of rupture and can be briefly characterised as follows. There can be no doubt that 1945 marked the threshold to a new phase in European modernity in which post-war reconstruction and the foundation of the EEC were the main achievements. It was an era of industrial capitalism and of economic growth in which a certain balance was forged between capitalism and democracy (Streeck 2014). The period in which social democracy and the welfare state consolidated entered into crisis in the early 1970s. The new era begins to take shape from 1973 when capitalism enters into a new phase and neo-liberalism by the 1980s emerges as the novel political force. It was a period when the new or cultural left emerges and new cleavages are formed. This pattern continues through the next phase, which is marked by the fall of the Berlin Wall, the end of the Warsaw Pact and the unification of Germany. From 1990 a New Europe takes shape with the consolidation of the EU and its later enlargement to include much of the former central and eastern Europe. This was an era of globalisation and the advancement of the neoliberal project. The current situation is characterised by the transition to a phase, which is marked by the global financial crisis of 2007-9 and the related, though different, problem of Greek debt, the unprecedented migration that followed the collapse of Libya and the war in Syria, and now Brexit and European wide rise of authoritarian populism. This is the era in which we are now in and it is not clear what the direction of travel is. In my view, one of the hallmarks of the present is the crisis of neoliberalism, which ran its course from the early 1980s to c 2008. The collapse of this ideology has opened up a space for new visions and ideas.

In this brief outline of the main points of rupture since the middle of the previous century, I am mainly concerned with stating the case for the presence, in fact, the persistence of continuity across those phases. I do not think, for instance, that the present day can be in any meaningful way compared with the rise of fascism in Europe in the 1930s. Brexit Britain has become an unpleasant place. Something profoundly changed 
since the 23rd June 2016. However, we do not have a throw-back to 1933 or even 1931. There is no project of re-armement, despite a rise in hate-crimes, the right-wing populism does not have militias out on the streets, parliamentary democracy is strong and there is nothing like spectre of the USSR challenging the West. Capitalism is more or less safe. Yes, to be sure the left is divided as it always has been, unlike the right. Authoritarian populism does not have a new ideology to offer in the way that the Hitler and Mussolini did. Instead, the appeal of authoritarian populism is due to a more diffuse platform of anti-establishment politics and attacks on cultural pluralism in the name of the nation first, but where the nation is defined in exclusionary terms to be what populists declare it to be.

My argument is that there is strong continuity with the post-war project of reconstruction and peace and that this common ground that constitutes the European heritage needs to be given greater recognition.

One of the great achievements of European integration is an issue that goes beyond the integration of states and economies and relates to the person as the bearer of rights and in particular human rights. As a result of the constitutionalisation of the EU, a complex framework of rights has been consolidated. The EU is without doubt a major global champion of human rights. Human rights are deeply embedded in domestic laws as a result of EU law. Through the EU Charter of Fundamental Rights, the European Convention of Human Rights (ECHR) and the case law of the European Court of Human Rights in Strasbourg, human rights are not abstract rights but enshrined in the legal framework of all member states. Although the EU may not be greatly popular, it has had a positive and far-reaching impact on the lives of Europeans. It has made possible greater gender equality in employment and it has brought about the prohibition of discrimination on grounds such as religion, sexual orientation, disability and age. The upshot of this is that equality has been given an important basis in European law. It could therefore be suggested that in certain aspects of the legal framework of the EU, in particular those that pertain to the rights of the individual, there are wider normative aspects to European integration and which offer bonds of unity through solidarity.

To the extent to which it still holds normative force, the vision of a post-national Europe based on citizenship is not entirely devoid of substance. In several publications Habermas (2001) defended the republican idea of Europe based on citizenship. The challenges to this normative model are now considerable and derive from systemic failure due to the nature of the single currency, which has led to new divisions within the member states. Despite these problems, it is arguably the case that the normative foundation of the EU is the individual, not the state. This is probably the most important legacy of the EU. It is an example of what I see as the enduring feature of contemporary Europe and which may offer an antidote to its divisions. However, at the moment these normative ideas around the rights of the individual etc. have set one stratum of the population - cosmopolitan liberals - against another stratum that sees national collectivity to be endangered.

The centrality of the individual has been one of the abiding features of the European legacy. It has been the integral to the liberal and the cosmopolitan tradition of thought. It is possible to see a clear link between the idea of Europe and the respect for the individual. In the cosmopolitical tradition of thought going back to Kant, it was expressed 
in the idea of hospitality. In Perpetual Peace in 1795 Kant established the principle of hospitality as the defining tenet of cosmopolitanism, which he contrasted to internationalism, which for Kant was based on treaties between states. Cosmopolitanism, in contrast, is based on the centrality of the individual and the need for the rights of the individual to be recognised even where the individual is a foreigner. It is this idea of cosmopolitan law, rather than the vision of global government, which Kant believed was desirable but not realistic, that has been the main legacy of modern cosmopolitanism. Its relevance to contemporary Europe cannot be underestimated.

While liberalism and cosmopolitanism have emphasised the centrality of the individual, on the other side, is the tradition of collective solidarity as represented by socialism and its various offshoots, chartism, social liberalism, social democracy. It can be argued that the concern with social justice is also one of the defining features of European modernity, an argument I have made in previous publications. A strong current in European history is resistance to a model of society based on the market. This can be variously related to anti-capitalist movements from socialism to social liberalism and social democracy. It is also what underpins the idea of a social model of capitalism that triumphed in western Europe in the post-1945 period. In the final analysis this is what distinguishes Europe from the rest of the world, that is the domestication of capitalism by political claims for social justice. In this sense, then, the language of social justice and solidarity entered into the political systems of modern Europe in at least two ways. One in the shaping of social policies, which is often what is meant by solidarity. The other is in a more general normative conception of society. Both of these senses are also reflected in the core documents of the EU, for examples solidarity is mentioned in the Treaty of Rome in 1957 and the Charter of Fundamental Rights in 2000. In the latter case it signifies social policies and in the former case a more general and elusive normative conception of society as both a goal and as an assumption.

What is now needed is a fundamental shift in the very conception of Europe to more fully capture solidarity. This is more important than issues of mobility, markets or supranational governance. My analysis suggests that the nation is no longer able to deliver social justice without connecting with a larger sense of political community. This may be the most viable opportunity for the reinvention of European political community. Looking at things in this way also shows how the cosmopolitical perspective connects with the social justice tradition.

Rather than start with the divisions, I have preferred to begin with an account that foregrounds the unifying ideas, what I call ideas of Europe. This is also because these ideas are present and make possible progressive counter-trends that contain within them the seeds of future possibilities. Moreover, to speak of crisis requires a perspective on critique, since it makes no sense to speak of something being in crisis if it is not clear what it is that is in crisis. It is a well-stablished position in German social theory that crisis and critique are connected.

I am firmly of the belief that cosmopolitical trends are strong. In fact, an emerging feature of current times is the onset on a new cleavage that can be characterised in terms of two competing conceptions of the nation, an open versus a closed conception of the national community. The open one is infused with cosmopolitical currents, while the closed one is anti-cosmopolitan and animated by a pervasive resentment that encompasses anything that cannot be defined through the lens of a narrow view of the 
national community. I am not describing this as one between the nation and Europe, but an inner conflict or tension within the category of the nation. The major conflicts of the present are within nations, not between them or between the nation and Europe. Contemporary societies are highly divided.

There have been two major cleavages that have cut across most (western) European societies since 1945, but to which we must now add a third cleavage. The first is the conflict over the distribution of wealth. This cleavage between the classes was expressed in the established political parties of the Right and Left and did not address cultural issues (religion, family and patriarchy remained untouched). It has now ceased to be the dominant cleavage, but is not irrelevant. Since the 1980s another cleavage became apparent, which complicated the older one and in which left versus right lost its clear-cut edge. The politics of radical pluralism that emerged from the cultural politics of the new left (e.g. feminism, environmentalism) since the 1960s challenged both the old left and the established right, but it had to face a new challenge from the New Right and by the 1990s, the lines of division between the old and new left had become blurred. Nonetheless there was a new division between cultural pluralists - those who value quality of life, post-material values, the rights of individuals around gender and race issues, alternative life styles - and the New Right (who often relied on cultural authoritarianism, e.g. family and religion, monarchy). To be sure, in this cleavage the older critique of capitalism lost its potency.

Since the early 2000s, a new cleavage arose following the rise of cosmopolitan political movements that unlike earlier left-wing movements were not confined to the parameters of the nation-state and also challenged the very meaning of the nation. Since the Global Social Forum and anti-capitalism movements such as Occupy Wall Street since 2008, this cleavage has become a potent structuring force in national and global politics. The rise of cosmopolitics has increasingly led to a new cleavage between those who largely identify with the nation and those who do not. This cleavage is driven by one-nation nationalism and populist reaction to globalisation, but is also antagonistic to radical cultural pluralism; it draws on right and left currents. We are thus witnessing a situation of the diminishing influence of the national culture on many people whose habitus is increasingly more plural, if not hybrid, and whose lifeworld has been transformed by anti-authoritarian and post-material values. This value divergence is now very great and underpinned by very different kinds of work and increased diversity. In the UK this group is likely to be Europeanised in their self-identification and in their life-styles, but will reflect different positions within the left/right wing divide. The Brexit Referendum is an example of this division within the national community to a point that the very unity of the national culture is in question (Delanty 2017). The two sides cross-cut the other cleavages. The cosmopoliticals (the Remain voters) are in the tradition of the new left, the cultural left, but also include neo-liberals and Euro-technocrats; the Nationals, the Brexiters, include the Old Left as well as the authoritarian nationalists, as in the Tory right/UKIP. This latter group has not been a significant force in British politics until recently. This is generally the case across. France, which narrowly escaped the election of Marine Le Pen to the presidency in 2017, is an even more dramatic example of a country that invented the Right and Left, but has now redrawn the political landscape between the Centre and the Extreme Right. 
It is very likely that this cleavage will be the defining feature of European politics for some time to come. These problems are not specific to Europe. Trump is the product of a similar dynamic. Many of the world's major democracies - the USA, Turkey, Brazil, even Russia - are beset by internal conflict along similar lines. The full implications of Brexit, Trump and the assent of radical authoritarian populism remain to be seen. In view of the immediate aftermath in the second half of 2016, it is now all the more evident that the post-1945 social and political order has come to an end. This was first heralded with the rise of neo-liberalism in the 1980s. The neoliberal revolution and the concomitant unleashing of the forces of economic and technological globalisation offered a vision of a possible alternative for much of the 1990s until the great crisis of 2008 when, private debt became an unsustainable substitute for public debt. The period of crisis from 2008 can be seen in the prophetic words of Antonio Gramsci in his Prison Notebooks an interregnum: 'The crisis consists precisely in the fact that the old is dying and the new cannot be born; in this interregnum a great variety of morbid symptoms appear.' Brexit and Trump are products of the interregnum. They are less an antidote than a symptom of the problem. What is this problem?

The problem is in part the false solutions that neoliberalism gave to the world for the problems of capitalist accumulation, which in valorising the market above all else have now exacerbated the fiscal crisis of the state to which neoliberalism was supposed to be the solution. Neoliberalism deployed the state in order to liberate the market, but in so doing it destroyed the integrative capacities of the state. Whether or not there will be a Polanyi style counter-movement in the form of an affirmation of social protection against the market remains to be seen. It is evident that this counter-movement will not come from authoritarian populism. Yet, much of the discontent that drives this does come from the social malaise created by capitalism. This certainly does not explain the phenomenon of authoritarian populism entirely - take the examples of the Netherlands and Austria - but it does account for its impetus. Variations certainly exist: Brexit is to a large extent driven by neoliberals. The British Brexiters see the EU as imposing limits that might be cast off in a new kind of buccaneering capitalism on the high seas. Where is democracy in all of this?

The current situation leaves democracy in a poor condition. Capitalism is undermining democracy at a time when democracy itself is taking illiberal forms. Here again Brexit looks large. Referendums, for example, can easily be instruments of authoritarian democracy when they seek to address major societal issues that are undefined and have multiple meanings (as, for example, what it means 'to leave' the EU). While a serious challenge for the left and for progressive politics, it would be a mistake to see authoritarian populism as something fundamentally new and aberrant revolutionary force that is contrary to democracy. It is rather protean, contradictory and volatile and enabled by democracy, which allows for popular expressions of resentment. The success of right-wing populism in Europe and in the USA can also be attributed to the fact that mainstream democracy the main political parties and the wider public sphere - has nurtured its values. As David Runciman (2013) has argued, the factors that make democracy successful - its flexibility, variety, and responsiveness - also serve to undermine it and encourage democracies to make mistakes. Democracies have safeguards against tyranny and demagogues, but ultimately cannot stop them nor prevent crises. The success of democracy is a trap, 'a confidence trap' that fails to warn that it also includes the bad as well as the good. Jan-Werner 
Müller (2016: 6) has made a similar argument that the danger to democracies is not in some kind of a counter-democratic ideology, but comes from within democracy, as in claims of populists 'to make good on democracy's highest values.'

In other words, right-wing populism is not a new or aberrant political phenomenon but is a radicalisation of issues and ideas in mainstream politics. One powerful source is popular resentment, which can be target against almost anything. This has already had considerable impact in changing the terms of much of public debate and many of the mainstream political parties on the right have been close to its values, e.g. the Spanish Popular Party, the British Conservative Party, and the French Republican Party. In the Nordic countries, the success of right wing populism can be in part attributed to social democracy in so far as it produced a vision of a homogenous society. Populist politics owes much of its success to radicalising centre right and centre left values. Thus, while radicalising cultural authoritarianism, right-wing populism often takes on board left wing social values in relation to social security and equality. Right-wing populism amplifies the defects and failures of liberal democracy. Counter-strategies based only on anti-populism are therefore not only destined to fail, but will fuel the very forces that authoritarian populism thrives on, since the message can only be let's trust the elites.

While the right can cope with authoritarian populism, the left is caught in a trap, since many of its supporters are drawn to right-wing populism. It makes no sense calling for anti-populist politics, when the discontent that fuels it is not given an alternative political form. While there are some examples of left-wing populism, they are relatively marginal and do not have the capacity to mobilise mass publics around a different set of values. Public discussion on the pros and contras of European integration concentrate too much on mobility and, as the Brexit issue revealed, too much on its economic merits.

I have concentrated on the internal cleavages within national political communities, but of course there are other ones: The division between East and West has now been complicated by a division between North and South, or between creditor and debtor countries. Here, too, the divisions are fuelled by capitalism and exacerbated by the structural flaws of the single currency (Offe 2015). The left was never truly happy with European integration and initially there was some resistance. But the politics of the centre left by the 1980s had become fully Europeanised. This has now led to a situation in which the left has no real rationale. The ProEU movement in the UK - which probably commands a majority - has only instrumental arguments around mobility and the advantages of the single market. The Brexit side has no instrumental arguments for Brexit but emotive and non-rational values that have considerable support. What is needed is a left-wing populism. This cannot be a left-wing Brexit, but one that is European in its-self-understanding. I have argued here strongly for greater recognition of the European heritage as a carrier of the cosmopolitan values of solidarity and social justice, respect for the individual. These need to be given a strong cosmopolitical form and identified not only with the Europe of the EU but the Europe of nations. As I argued, the real conflict is not between Europe and its nations but different and competing conceptions of what the nation stands for. I believe it is possible for the idea of the nation to be given a more European identity and in a way that avoids the populism vs. anti-populism. 


\section{Endnotes}

${ }^{1}$ This essay was delivered as a keynote lecture, Böckler Foundation, Dresden, Germany, 27th October, 2017. I am grateful to Professor Heinz Sünker for inviting me to give the lecture. The essays draws from my book, The European Heritage: A Critical Re-Interpretation (Routledge, 2018).

Acknowledgements

Not applicable.

Funding

Not applicable.

Availability of data and materials

Not applicable.

Authors' contributions

The author read and approved the final manuscript.

Competing interests

The author declares that he has no competing interests.

\section{Publisher's Note}

Springer Nature remains neutral with regard to jurisdictional claims in published maps and institutional affiliations.

Received: 1 December 2017 Accepted: 31 January 2018

Published online: 12 February 2018

\section{References}

Delanty, G. 2017. A divided nation in a divided Europe: Emerging cleavages and the crisis of European integration. In Brexit: Sociological Responses, ed. William Outhwaite. London: Anthem Press.

Delanty, G. 2018. The European heritage: A critical re-interpretation. London: Routledge.

Habermas, J. 2001. The Postnational constellation. Cambridge: Polity Press.

Harrington, A. 2016. German Cosmopolitan Social Thought and the Idea of the West. Cambridge: Cambridge: Cambridge University press.

Müller, J.-W. 2016. What is populism? Philadelphia: University of Pennsylvania University Press.

Offe, C. 2015. Europe entrapped. Cambridge: Polity Press.

Rosenboim, O. 2017. 2017 The Emergence of Globalism: Visions of World Order in Britain and the United States, 1939-1950 Princeton University Press.

Runciman, D. 2013. The confidence trap: A history of democracy in crisis from world war 1 to the present. Princeton: Princeton University Press.

Strath, B. 2016. Europe's utopias of peace. London: Bloomsbury Academic Press.

Streeck, W. 2014. Buying time: The delayed crisis of democratic capitalism, 2014. Cambridge: Polity Press.

\section{Submit your manuscript to a SpringerOpen ${ }^{\circ}$ journal and benefit from:}

- Convenient online submission

- Rigorous peer review

- Open access: articles freely available online

- High visibility within the field

- Retaining the copyright to your article

Submit your next manuscript at $\gg$ springeropen.com 